\title{
Compression Strength of Brazilian Exotics Wood Species Perpendicular to the Grain
}

\author{
Diego Henrique de Almeida ${ }^{1, *}$, Tiago Hendrigo de Almeida ${ }^{2}$, Fabiane Salles Ferro ${ }^{3}$, \\ André Luís Christoforo ${ }^{4}$, Francisco Antonio Rocco Lahr ${ }^{5}$
}

\author{
${ }^{1}$ Department of Civil Engineering (DECIv), Federal University of São Carlos (UFSCar), São Carlos, Brazil \\ ${ }^{2}$ Department of Materials Engineering (SMM), Engineering School of São Carlos (EESC), São Paulo University (USP), São Carlos, Brazil \\ ${ }^{3}$ Department of Forestry, State University of Paraná (UNICENTRO), Irati, Brazil \\ ${ }^{4}$ Faculty of Engineering and Architecture, FUMEC University, Belo Horizonte, Brazil \\ ${ }^{5}$ Department of Structures Engineering (SET), Engineering School of São Carlos (EESC), São Paulo University (USP), São Carlos, Brazil
}

\begin{abstract}
Wood is a natural material that present variability of their properties. When used as ties in railways or as bridges decks, wood is request with compressive loads in direction perpendicular to the grain. The aim of this research is determining the compressive perpendicular to the grain strength $\left(\mathrm{f}_{\mathrm{c} 90}\right)$ of two Brazilian exotic wood species. Tests were carried out using wood of Corymbia (Corymbia citriodora) and Pinus (Pinus taeda L.). Specimens and test methods were realizes according to Brazilian Standard Code ABNT NBR 7190:1997 (specimens at 12\% of moisture content). Compressive perpendicular to the grain strength values to Corymbia and Pinus were equal to $17.00 \mathrm{MPa}$ and $3.60 \mathrm{MPa}$, respectively. More studies about mechanical and physical properties of wood is important to rationalize their uses and provide greater knowledge about this material.
\end{abstract}

Keywords Corymbia, Mechanical properties, Pinus, Wood

\section{Introduction}

Around the world search for materials that harm the possible minimum the environment is a practice carried out by all segments of the economy. Wood has always been one of the main materials used by mankind. In civil construction, wood is one of the main materials used and with new technology in the industry it is standing out more and more, even, because it is a sustainable when coming from certified forests $[1,2]$.

Studies concerning the physical and mechanical properties of wood show that this material is extremely heterogeneous. The wood has physical, strength and stiffness properties different between species (conifer or dicotyledonous), between individuals of the same species and even when removing specimens from different points of the same tree (heartwood or sapwood) [3-6].

Others factors in addition to the determination of physical and mechanical properties are important for its use, such as pre-treatment with chemicals products to protect them against the action of wood decay organisms [7, 8], its use in places where there is not the contact with water directly to

* Corresponding author:

diegoestruturas@gmail.com (Diego Henrique de Almeida)

Published online at http://journal.sapub.org/jce

Copyright (C) 2017 Scientific \& Academic Publishing. All Rights Reserved prevent its deterioration (to rot), as the wood is susceptible to moisture [9-11]. For all these reasons, it is important studies of physical and mechanical properties of wood for use in several purposes [12].

The Brazilian Standard Code ABNT NBR 7190: 1997 [13] provides methods of laboratory tests to determine the physical and mechanical properties of wood.

A mechanical property of wood that must be taken into account in design of timber structures is the compression perpendicular to grain strength. In many cases the wood is requested with compressive loads in this direction, for examples, when it is used as ties in railways [14] or as bridges decks [15].

The aim of this research is the experimental determination of the compression perpendicular to the grain strength of two Brazilians exotics wood species.

\section{Material and Methods}

Tests were carried out in Wood and Timber Structures Laboratory (LaMEM), Structural Engineering Department (SET), São Carlos Engineering School (EESC), São Paulo University (USP), Brazil.

For this research was used wood from exotic trees planted forests in Brazil: Pinus (Pinus taeda L.) from Paraná state and Corymbia (Corymbia citriodora) (Fig 1) from São Paulo state. For each wood species were prepared 13 specimens 
(one needed to estimate the compressive perpendicular to grain strength $\left.-\mathrm{f}_{\mathrm{c} 90, \text { est }}\right)$. Wood specimens had $12 \%$ of moisture content, according to ABNT NBR 7190: 1997 [13].

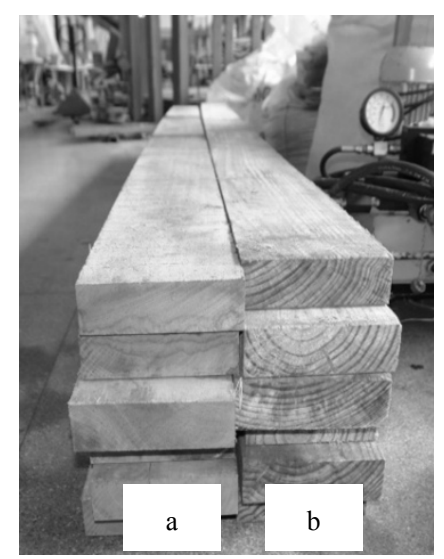

Figure 1. (a) Members for preparation of specimens: (a) Corymbia; (b) Pinus

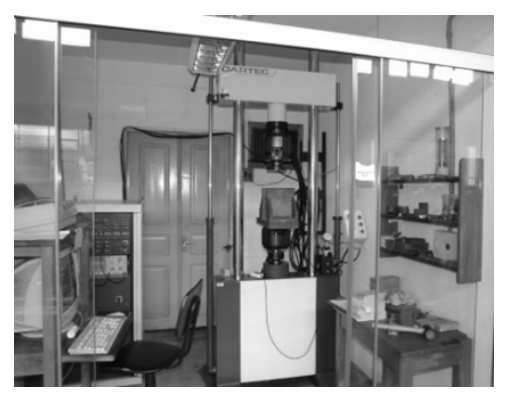

(a)

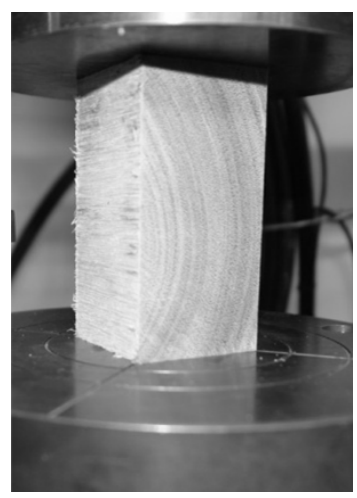

(b)

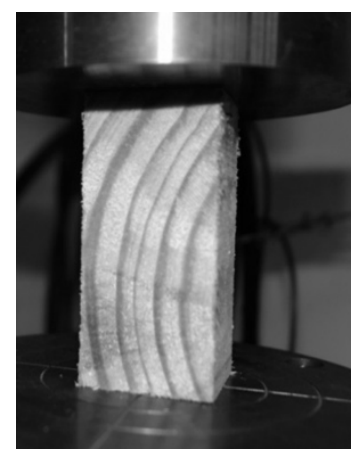

(c)

Figure 2. (a) Universal testing machine electronic Dartec; Tests with (b) Corymbia; (c) Pinus specimens
Tests occurred in the electronic universal testing machine Dartec with load capacity of $100 \mathrm{kN}$ (Fig. 2).

The load required to rupture the specimen in test of compression perpendicular to grain $\left(\mathrm{F}_{\mathrm{c} 90}\right)$ is agreed to a graphical method (Fig. 3) [16]. The compression perpendicular to grain strength $\left(\mathrm{f}_{\mathrm{c} 90}\right)$ is provided by the ratio between $\mathrm{F}_{\mathrm{c} 90}$ and square cross-section area of the specimen (A), with $5 \mathrm{~cm}$ of square cross-section (Fig. 4), according to Eq 1.

$$
\mathrm{f}_{\mathrm{c} 90}=\frac{\mathrm{F}_{\mathrm{c} 90}}{\mathrm{~A}}
$$

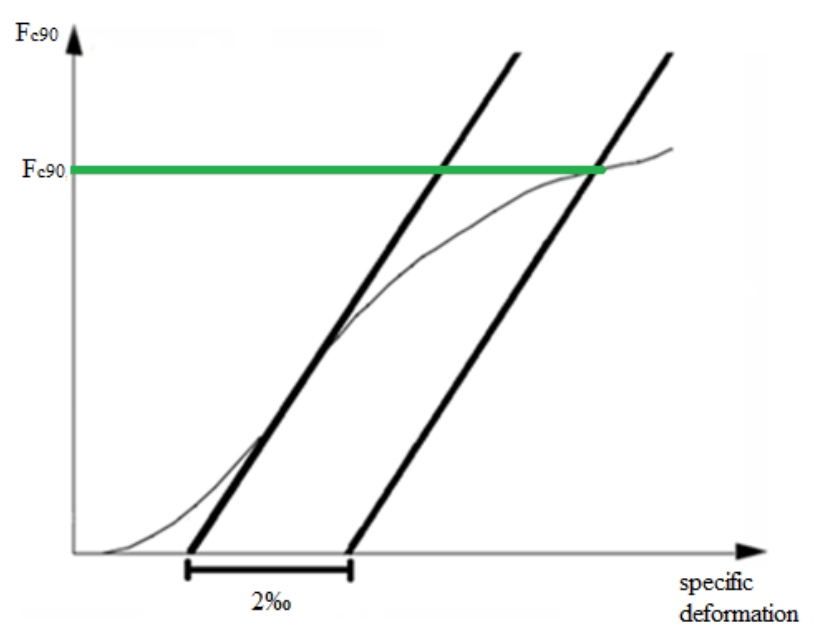

Figure 3. Compressive perpendicular to the grain load vs. specific deformation to $F_{c 90, \text { est }}[13]$

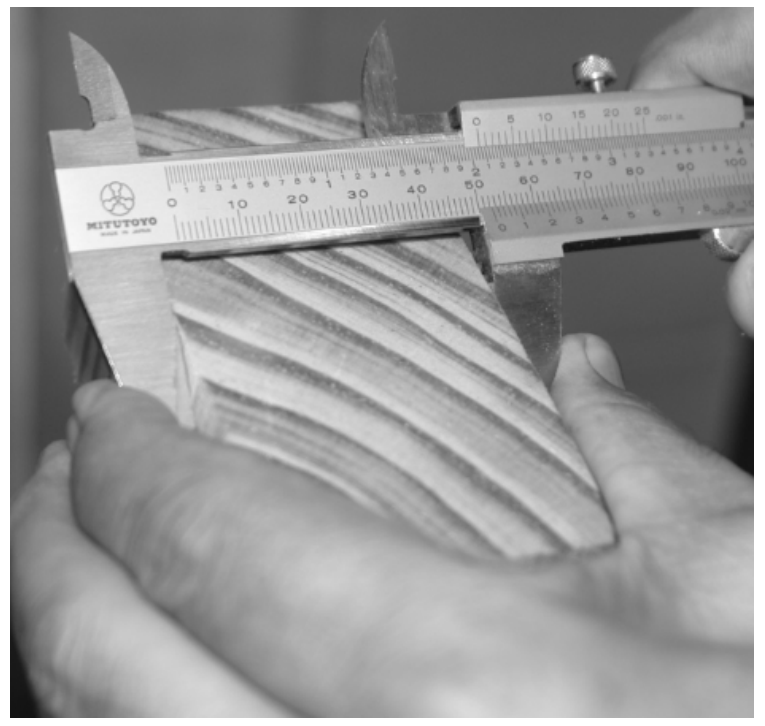

Figure 4. Pinus wood specie specimen size

\section{Results}

Table 1 presents the average values of compressive perpendicular to grain strength $\left(\mathrm{x}_{\mathrm{m}}\right)$, standard deviation $(\mathrm{Sd})$, coefficient of variation (CV) and number of specimens (n) for each of the species studied in this research (Pinus and Corymbia). 
Table 1. Average values of compression perpendicular to grain strength for Pinus and Corymbia

\begin{tabular}{ccc}
\hline $\mathrm{f}_{\mathrm{c} 90}[\mathrm{MPa}]$ & Pinus & Corymbia \\
\hline $\mathrm{n}$ & 12 & 12 \\
$\mathrm{x}_{\mathrm{m}}$ & 3.60 & 17 \\
$\mathrm{~S}_{\mathrm{d}}$ & 1.07 & 3 \\
$\mathrm{CV}[\%]$ & 30 & 18 \\
\hline
\end{tabular}

Compression perpendicular to grain strength determined for Corymbia was higher than that determined for Pinus. Corymbia is a dicotyledonous and, in addition, has a higher specific gravity than Pinus, which in turn is a conifer, this gives the greatest strength and stiffness properties for Corymbia [3-5].

The coefficient of variation of compressive perpendicular to grain strength of Pinus equal to $30 \%$ may be related to the amount of growth rings (winter and summer rings) that are present in the specimens and influence in determining the strength properties of wood $[17,18]$.

\section{Conclusions}

Studies about determination of the strength properties of wood are important for greater knowledge this material and to improve its use.

The average compression perpendicular to grain strength values of the Pinus determined in this study was lower than that determined for Corymbia.

\section{ACKNOWLEDGMENTS}

Authors thank to Wood and Timber Structures Laboratory (LaMEM), Structural Engineering Department (SET), São Carlos Engineering School (EESC), São Paulo University, by the materials and resources used in this research. Also, thank CAPES for financial supports.

\section{REFERENCES}

[1] Calil Neto, C. Glulam: quality control in combinations of species-adhesive-preservative treatment. São Carlos, 2011, 119 p. (Master's Dissertation, School Engineering of São Carlos, USP).

[2] Bertolini, M. S. Use of CCB treated of Pinus sp residues in particleboard production emplying polyurethane resin based on castor oil. São Carlos, 2011, 128 p. (Master's Dissertation, School Engineering of São Carlos, USP).

[3] Icimoto, F. H.; Ferro, F. S.; Almeida, D. H.; Christoforo, A. L.; Lahr, F. A. R. Influence of the specimen position on calculus of the bending modulus of elasticity, International Journal of Materials Engineering, 3 (2013) 41-46.
[4] Ferro, F. S.; Icimoto, F. H.; Almeida, D. H.; Christoforo, A. L.; Lahr, F. A. R. Verification of test conditions to determine the compression modulus of elasticity of wood, International Journal of Agriculture and Forestry, 3 (2013) 66-70.

[5] Lahr, F. A. R. About elasticity properties of wood determination. São Carlos, 1983, 216 p. (Doctoral Thesi's, School Engineering of São Carlos, USP).

[6] Almeida, D. H.; Molina, J. C.; Almeida, T. H.; Calil Junior, C. Analysis of embedment and compression strength of the reforestation wood, Proceedings of XIII Brazilian Meeting of Timber and Wood Structures, Vitória, Brazil, 2012.

[7] Icimoto, F. H.; Ferro, F. S.; Varanda, L. D.; Souza, A. M.; Almeida, D. H.; Christoforo, A. L.; Lahr, F. A. R. Physical and mechanical properties of Paricá wood species treated with CCB preservative, International Journal of Materials Engineering, 3 (2013) 82-86.

[8] Almeida, D. H.; Scaliante, R. M.; Cavalheiro, R. S.; Macedo, L. B.; Christoforo, A. L.; Macêdo, A. N.; Calil Junior, C.; Lahr, F. A. R. Wood-Adhesive-Waterproofing combinations in Glulam, Wood: Architecture and Engineering, 12 (2011) 9-17.

[9] Logsdon, N. B.; Calil Junior, C. Influence of the moisture content in the strength and stiffness properties of the wood, Books of Structures Engineering. EESC, 18 (2002) 77-107.

[10] Silva, D. A. L.; Lahr, F. A. R.; Faria, O. B.; Chahud, E. Influence of wood moisture content on the modulus of elasticity in compression parallel to the grain, Materials Research, 15 (2012) 300-304.

[11] Scaliante, R. M.; Almeida, D. H.; Macedo, L. B.; Macêdo, A. N.; Calil Junior, C. Creep and compression parallel to grain tests for woods in equilibrium moisture and saturated situations, Wood: Architecture and Engineering, 12 (2011) 19-30.

[12] Calil Junior, C.; Lahr, F. A. R.; Dias, A. A. Timber elements design, Manole, 2003.

[13] ABNT NBR 7190:1997. Design of Structure of Timber. Rio de Janeiro, 1997.

[14] Icimoto, F. H. Wood and glulam ties made with Pinus oocarpa, Itapeva, 2011, 104 p. (Graduate Monograph, Paulista Estate University, UNESP).

[15] Dias, A. A. Study about the compression normal to the grain. São Carlos, 1994, 159 p. (Doctoral Thesi's, School Engineering of São Carlos, USP).

[16] Almeida, D. H.; Molina, J. C.; Almeida, T. H.; Calil Junior, C. Analysis of strength and stiffness of wood from reforestation in compression loads, Proceedings of XIII Brazilian Meeting of Timber and Wood Structures, Vitória, Brazil, 2012.

[17] Carreira, M. R. Rulles for visual grading of structural lumber of Pinus sp. São Carlos, 2003, 182 p. (Master's Dissertation, School Engineering of São Carlos, USP).

[18] Amaya, M. L. C. Reinforcement finger joints with fibers composites in pieces of wood. São Carlos, 2013, 95 p. (Master's Dissertation, School Engineering of São Carlos, USP). 